\title{
Dentist's Knowledge Level about Early Treatment for Maxillary Sinus Perforation in District Helvetia Medan 2017
}

\author{
Hendry Rusdy, Bella Risqi \\ Department Oral and Maxillofacial Surgery \\ Faculty of Dentistry, Universitas Sumatera Utara \\ Medan, Indonesia \\ bellarizkyy@yahoo.co.id
}

\begin{abstract}
Maxillary sinus perforation is one of complication from tooth extraction that could create a connection between antrum and oral cavity (oroantral communication). The aim of this research is to determine the level of dentists' knowledge about the initial treatment to handle the sinus maxillary perforation in District Helvetia, Medan in year 2017. This research is a descriptive survey; the population is every dentist in District Helvetia, Medan. The population is made as the sample (total sampling), so the amount of the sample in this research is 56 people. The results showed us that there is $69.64 \%$ of the dentist are categorizes as knowledgeable, $30.36 \%$ of dentists are knowledgeable enough and $0 \%$ of the dentist are categorized as not knowledgeable. The level of dentist knowledge about the initial treatment to handle the sinus maxillary perforation in District Helvetia, Medan in year 2017, 69.64\% knowledgeable, $30.36 \%$ knowledgeable enough and no one is not knowledgeable.
\end{abstract}

Keywords-knowledge, dentist, perforated maxillary sinus, oroantral communications

\section{INTRODUCTION}

Maxillary sinus perforation is one of the complications in tooth extraction. The maxilary sinus is a potentially complicated area when there is an upper molar extraction [2]. Maxillary sinus perforation can lead to the formation of oroantral communication (OAC). OAC is a pathological condition of the relationship between nasal cavity/antrum with oral cavity. This relationship is a complication of maxillary posterior tooth extraction than has an incience ranging from $0.31 \%-3.8 \%[1,3,5]$.

The formation of OAC can cause some symptoms in patients such as, water and air passing through the nose and mouth. The diameter of OAC usually decreases but sometimes the antrum to the mouth's path fail to heal and become a layered epithelium, if this occurs, it means the relationship between the antrum and the nose can be a fistula (oroantral fistula/OAF). The fistula is a pathway for infection and can cause acute sinusitis that inhibits the healing's process $[2,3,4]$.

The etiology of OAC is a complication after extraction of the posterior maxillary tooth or molar palatal root fracture, the destruction of sinus's base due to periapical abnormalities, as well as the perforation of the sinus and sinus membrane that caused by incorrect use of the instrument. The root of the first and second upper molars have a close relationship with the maxillary sinus $[3,6,9]$.

Under normal conditions, if OAC occurs due to tooth extraction, healing process will occur if the blood clot in the socket is not disturbed. If a blood clot breaks out or there is deficiency due to infection, then the canal will be coated by epithelium layer and will develop into an oroantral fistula (OAF). After the diagnosis of OAC is established, the management of OAC should be performed immediately. Therefore, a dentist should have the knowledge of the management and initial of handling OAC due to maxillary sinus perforation $[3,7,9]$.

\section{MATERIALS AND METHODS}

This study is a descriptive survey to describe dentists' knowledge level about the initial treatment for maxillary sinus perforation in dentists' practice in District Helvetia, Medan. The location for this research was at dentists' practice in District Helvetia, Medan and conducted on February 2017. The population of this research is every dentists who practices in District Helvetia, Medan. The entire population are the sample (total sampling), so the total samples are 56 people. Data obtained from the questionnaire filling.

\section{RESULTS}

Table I shows you the respondent's characteristics description of the initial handling of sinus perforation in District Helvetia, Medan. In this research, it shows that there are 56 dentists, which is $32 \%(75.14 \%)$ of women and $24(42.86 \%)$ of men.

TABLE I. THE RESPONDENTS CHARACTERISTICS

\begin{tabular}{|c|c|c|}
\hline \multicolumn{3}{|c|}{ DESCRIPTION } \\
\hline Sex & $\mathbf{N}$ & \% \\
\hline Men & 24 & $42.86 \%$ \\
\hline Women & 32 & $57.14 \%$ \\
\hline Total & 56 & $100 \%$ \\
\hline
\end{tabular}


TABLE II. THE RESPONDENTS' KNOWLEDGE DISTRIBUTION ABOUT EARLY TREATMENT OF MAXILLARY SINUS PERFORATION

\begin{tabular}{|c|c|c|c|c|c|}
\hline \multirow{2}{*}{\multicolumn{2}{|c|}{ Knowledge }} & \multicolumn{2}{|c|}{ Know } & \multicolumn{2}{|c|}{ Do Not Know } \\
\hline & & $n$ & $\%$ & $\mathrm{n}$ & $\%$ \\
\hline 1. & $\begin{array}{l}\text { The definition of } \\
\text { maxillary sinus } \\
\text { perforation and OAC. }\end{array}$ & 54 & 96.43 & 2 & 3.57 \\
\hline 2. & $\begin{array}{l}\text { The etiology of } \\
\text { maxillary } \\
\text { perforation }\end{array}$ & 52 & 92.86 & 4 & 7.14 \\
\hline 3. & $\begin{array}{l}\text { Early complication of } \\
\text { maxillary sinus } \\
\text { perforation }\end{array}$ & 31 & 55.36 & 25 & 44.64 \\
\hline 4. & $\begin{array}{l}\text { How to diagnose the } \\
\text { maxillary sinus } \\
\text { perforation }\end{array}$ & 50 & 86.29 & 6 & 10.71 \\
\hline 5. & $\begin{array}{l}\text { The handling of } \\
\text { maxillary sinus } \\
\text { dilation and divergent } \\
\text { root }\end{array}$ & 33 & 58.93 & 23 & 41.07 \\
\hline 6. & $\begin{array}{l}\text { OAC preventon } \\
\text { caused by maxillary } \\
\text { sinus perforation }\end{array}$ & 52 & 92.86 & 4 & 7.14 \\
\hline 7. & $\begin{array}{l}\text { How to give sinus } \\
\text { precaution }\end{array}$ & 100 & 100 & 0 & 0 \\
\hline 8. & $\begin{array}{l}\text { Ealy treatment for } 2 \\
\text { mm OAC }\end{array}$ & 32 & 57.14 & 24 & 42.86 \\
\hline 9. & $\begin{array}{l}\text { Early treatment for } 2- \\
6 \mathrm{~mm} \text { OAC }\end{array}$ & 41 & 73.21 & 15 & 26.79 \\
\hline 10. & $\begin{array}{l}\text { Early treatment for } \\
\text { more than } 6 \mathrm{~mm} \text { OAC }\end{array}$ & 52 & 92.86 & 4 & 7.14 \\
\hline
\end{tabular}

The data in table II shows the dentist's knowledge about the definition, etiology and diagnosis for maxillary sinus perforation.

\section{DISCUSSION}

In terms of knowledge, it shows that $96.43 \%$ of respondents know the definiton of maxillary sinus perforation. The definition is the pathological state of the relationship between the nasal cavity with the oral cavity, which is a complication after posterior maxillary tooth extraction. This condition shows that maxillary sinus perforation is a basic knowledge that must be owned by a dentist $[3,6]$.

The respondents' knowledge of the etiology of OAC is also categorized well because $92.8 \%$ of respondents answered correctly. This shows that those respondents know how OAC can occur; it is comparable to the knowledge of the respondent about the definition of maxillary sinus perforation. The etiology of OAC is a complication after extraction of the maxillary posterior tooth or palatal fracture of the root molar tooth, the destruction of the sinus base due to periapical and as well as the perforation of sinus and sinus membrane due to incorrect use of the instrument $[3,5]$.

The respondents' knowledge level about the initial complications of maxillary sinus perforation is categorized as enough because there's only $55.36 \%$ of respondents responded appropriately. The initial complication of perforation of the maxillary sinus is the formation of a relationship between the nasal cavity and the oral cavity [3]. This condition may be caused by the majority of the respondents answered that an oroantral fistula is the final complication if OAC is not treated, but $89.29 \%$ of respondents know about the initial diagnose of maxillary sinus peforation, while $10.71 \%$ has not responded correctly. This shows us the good results because the respondents know how to determine a situation of maxillary sinus perforation by pressing the patient's nose with the fingers and the mouth wide open and told the patient to breathe through the nose and then use the vision directly with the glass mouth to see the presence of air mixed with blood coming out of the hole [3].

The respondents' knowledge level on initial treatment if there is radiographic representation with dilated sinus and divergent root morphology is categorized sufficiently, because $58.93 \%$ of respondents respond appropriately. Conditions that there is a dental root diverging a dentist should make informed consent and inform the patient of any complications that may occur. Informed consent before the maxillary tooth extraction is one of the most important actions, this is because of the high risk of postoperative OAC removal. Informed consent prior to the removal of the maxillary posterior tooth is one of the most important acts, given the high risk of postoperative tooth extraction, if from the radiographic picture it is known that the maxillary sinus size is widened due to the age and the morphology of the root tooth is divergent, avoid intraalveolar tooth extraction and do the teeth separation technique first and remove the parts of the teeth one by one so that post trauma tooth trauma can be minimized [5,7].

23 respondents answered by intraalveolar tooth extraction, the tooth extraction by intraalveolar technique in the teeth closest to the sinus should be avoided to reduce the pressure on the sinus wall and choose the separation technique [3]. According to Kanagasabapathy Thirumurugan et al in 2013 there are several complications from maxillary tooth extraction by intraalveolar technique. The complications are the entry of teeth and roots into the maxillary sinus cavity, alveolar bone fracture, maxillary tuberosity fracture, intraorbital hematoma, and oroantral communication (OAC) formation. The situation may be caused by the respondents not understanding the definition of intraalveolar tooth extraction techniques that should be done with the separation technique [10].

$92.86 \%$ of respondents know about how to prevent the occurrence of $\mathrm{OAC}$, that is with good selfpreparation, periapical radiography to determine the root morphology and gear distance with maxillary sinus, and the use of appropriate instruments. This condition may be caused because the question is a basic thing to do to prevent the occurrence of complications due to tooth extraction, especially perforation of the maxillary sinus [4].

$100 \%$ of respondents know about sinus precaution which are avoid blowing, sucking saliva, sucking the socket, drinking through straw, or smoking. Prevention of OAC can be done with better self preparation and importance of knowing the anatomy of posterior maxillary teeth and the maxillary sinus. This condition may be due to this question of prequalifying basic knowledge and sinus precaution is one of the instructions that is often given by dentists to patients after tooth extraction [5]. 
The respondents' knowledge about the handling of OAC with diameter of $2 \mathrm{~mm}$ is sufficiently categorized, because $57.14 \%$ responded appropriately and $42.86 \%$ responded incorrectly. The only action required is to press the socket with a tampon for 1-2 hours and provide post-extraction instructions with special treatment on the sinus or (sinus precaution) during the first 24 hours. $73.21 \%$ of respondents answered correctly about the 2-6 $\mathrm{mm}$ diameter OAC handling. The respondents's knowledge level is categorized well. The action that needs to be done is to place the sponge gauze and suture of the socket of the tooth with figure eight pattern to keep the blood clot in the socket, plus the precaution sinus instruction for 10-14 days and the administration of antibiotic drugs, such as penicillin or clindamycin for five days, and oral and nasal spray decongestants to keep the ostium in good condition so that no maxillary sinusitis occurs [5].

The respondent's knowledge level about OAC handling diameter greater than $6 \mathrm{~mm}$ is categorized good because $92,86 \%$ respondent answer correctly, action need to be done is closing socket with flep so that happened primary closure. Flep should be free of tension and the flep position should be located above the bone. Variations of flep types that are often done for OAC closure include buccal flep, palatal flep, buccal fat pad, gold foil, and so forth. This condition may be caused by the given question is basic but in a $2 \mathrm{~mm}$ OAC that is sufficiently knowledgeable, it may be because the respondent is unaware of the difference in the initial handling of OAC that sized between $2 \mathrm{~mm}$ and 2-6 $\mathrm{mm}$ [3].

Based on research conducted in dentist practice on initial handling of sinus perforation in District Helvetia, Medan in year 2017, it was found that dental knowledge on understanding, etiology, diagnostics, prevention of oroantral communication, precautionary method, and initial handling of medium-sized (2-6mm)
$\mathrm{OAC}$ and larger (more than $6 \mathrm{~mm}$ ) enters into either category 76-100\%. The dentist's knowledge of the early complications of maxillary sinus perforation, the action when there is known to be dilated maxillary sinus and divergent roots, and the initial handling of $2 \mathrm{~mm}$-sized OAC into the sufficient category of $56-75 \%$. The level of knowledge of the dentist on the initial handling of maxillary sinus perforation in Medan Helvetia District in $2017,69.64 \%$ is categorized as well knowledgeable and $30.36 \%$ knowledgeable enough. No dentist is categorized as less knowledgeable.

\section{REFERENCES}

[1] C. Ogunsalu, "A new surgical management for oro-antral communication the resorbable guided tissue regeneration membrane-bone substitute sandwich technique," West Indian Med. J., vol. 54(4), pp. 261-263, 2005.

[2] R.M Logan, E.A Coates, "Non-surgical management of an oroantral communication in a patient with HIV infection," Aust Dent. J., vol. 48(4), pp. 255-258, 2003.

[3] W. Poedjiastuti, "Komunikasi oroantral; etiologi dan penatalaksanaannya,” J. Gigi, vol. 4(8), pp. 116-119, 2006.

[4] N. Kumar, H. Bhutani, P. Jain, A. Verma, S. Tomar, S. Chaterjee, et al., "Accidental entry of foreign body in maxillary sinus a case report," J. Stomatology, vol. 5, pp. 1-5, 2015.

[5] I. Woo, B.T. Le, Management of complications of dental extraction. California: Academy of Dental Therapeutics and Stomatology a Division of Pennwell, 2008, 1-8.

[6] J.R. Hupp, E. Ellis, M.R. Tucker, Contemporary Oral and Maxillofacial Surgery, $6^{\text {th }}$ ed., St.Louis: Mosby Elsevier, 2014, 382-392.

[7] M.N. Anil, Textbook of oral and maxillofacial surgery. $2^{\text {nd }}$ ed., New Delhi India: Jaypee Brothers Medical Publishers (P) Ltd, 2008, 567-568

[8] S.M. Balaji, Textbook of Oral and Maxillofacial Surgery, Elsevier: New Delhi, 2007, 211-213.

[9] M.H. Chandra, Buku petunjuk praktis pencabutan gigi, Jakarta: Agung Seto, 2014, 1-2.

[10] K. Thirumurugan, R.R.B. Munzanoor, G.A. Prasad, K. Sankar, "Maxillary tuberosity fracture and subconjunctival hemorrhage following extraction of maxillary third molar," J. Nat. Sci. Biol. Med., vol. 4(1), pp. 242-245, 2013 